\title{
PAPAYA PULP GELLING : IS IT PREMATURE RIPENING OR PROBLEMS OF WATER ACCUMULATION IN THE APOPLAST?
}

\author{
JURANDI GONÇALVES DE OLIVEIRA², RICARDO ENRIQUE BRESSAN-SMITH², \\ ELIEMAR CAMPOSTRINI ${ }^{2}$, MAURA DA CUNHA ${ }^{3}$, ERNANI SANTOS COSTA ${ }^{4}$, \\ ALENA TORRES NETTO2 ${ }^{2}$ KELLY DA SILVA COUTINHO ${ }^{5}$, \\ MARCELO GOMES DA SILVA ${ }^{6}$, ANGELA PIERRE VITÓRIA ${ }^{7}$
}

ABSTRACT - Gelled aspect in papaya fruit is typically confused with premature ripening. This research reports the characterization of this physiological disorder in the pulp of papaya fruit by measuring electrolyte leakage, Pi content, lipid peroxidation, pulp firmness, mineral contents $(\mathrm{Ca}, \mathrm{Mg}$ and $\mathrm{K}$ - in pulp and seed tissues), and histological analysis of pulp tissue. The results showed that the gelled aspect of the papaya fruit pulp is not associated with tissue premature ripening. Data indicate a reduction of the vacuole water intake as the principal cause of the loss of cellular turgor; while the waterlogged aspect of the tissue may be due to water accumulation in the apoplast.

Index terms: ultrastructural alterations, cell turgor, fruit quality, physiological disturbances, biochemical alterations.

\section{GELEIFICAÇÃO DA POLPA DE MAMÃO: AMADURECIMENTO PREMATURO OU PROBLEMAS NO ACÚMULO DE ÁGUA NO APOPLASTO?}

RESUMO - O aspecto geleificado da polpa de mamão é constantemente confundido com amadurecimento prematuro. Este trabalho caracterizou esse distúrbio fisiológico na polpa de frutos de mamão através de medidas de liberação de eletrólitos, conteúdo de Pi, peroxidação lipídica, firmeza da polpa, condudo mineral (Ca, $\mathrm{Mg}$ e $\mathrm{K}$ - na polpa e semente) e análises histológicas da polpa. Os resultados mostram que o aspecto geleificado da polpa de mamão não está associado com o amadurecimento prematuro. Os resultados indicam uma redução da entrada de água no vacúolo como a principal causa da perda de turgor celular, enquanto o aspecto encharcado da polpa pode ser devido ao acúmulo de água no apoplasto.

Termos para indexação: alterações ultra estruturas, turgor celular, qualidade de frutos, distúrbios fisiológicos, alteraçõs bioquímicas.

\footnotetext{
'(Trabalho 243-09). Recebido em: 20-10-2009. Aceito para publicação em: 27-04-2010. Financial support: CNPq and FAPERJ. ${ }^{2}$ Laboratório de Melhoramento Genético Vegetal, Centro de Ciências e Tecnologias Agropecuárias, Universidade Estadual do Norte Fluminense, 28013-602, Campos dos Goytacazes-RJ, Brasil. E-mails: jugo@uenf.br (corresponding author) ; bressan@uenf.br; campost@uenf.br; alenatorres@msn.com.

${ }^{3}$ Laboratório de Biologia Celular e Tecidual, Centro de Biociências e Biotecnologia, Universidade Estadual do Norte Fluminense, 28013-602, Campos dos Goytacazes-RJ, Brasil. E-mail: maura@uenf.br

${ }^{4}$ Colégio Técnico Agrícola Ildefonso Bastos Borges, Universidade Federal Fluminense, 28360-000, Bom Jesus de Itabapoana-RJ, Brasil. E-mail: coutinhokelly@yahoo.com.br

${ }_{5}^{5}$ Departamento de Biologia Vegetal, Centro de Ciências Biológicas e da Saúde, Universidade Federal de Viçosa, 36570-000, ViçosaMG, Brasil

${ }^{6}$ Laboratório de Ciências Físicas, Centro de Ciência e Tecnologia, Universidade Estadual do Norte Fluminense, 28013-602, Campos dos Goytacazes-RJ, Brasil. E-mail: mgs@uenf.br

${ }^{7}$ Laboratório de Ciências Ambientais, Centro de Biociências e Biotecnologia, Universidade Estadual do Norte Fluminense, 28013 602, Campos dos Goytacazes-RJ, Brasil. E-mail: apvitoria@gmail.com
} 


\section{INTRODUCTION}

In the orchards of Linhares region $\left(19^{\circ} 39^{\prime} \mathrm{W}\right.$; $\left.40^{\circ} 07^{\prime} \mathrm{S}\right)$, Brazil, farmers and technicians have observed the occurrence of physiological disorder (PD) affecting fruit quality of Solo-type papaya (Carica papaya L. 'Golden'). This disturbance seems to occur seasonally (between May and July - season of moderate temperature - average of 22 ${ }^{\circ} \mathrm{C}$ ) and is characterized by a translucent pulp tissue that appears gel-like. The gelling symptoms do not necessarily occur in all fruits from the same tree and healthy fruits are harvested as well as the gelling fruit. In these fruits, the gelling tissue develops from the endocarp to the epicarp, similarly to pulp ripening (ROSETTO et al., 2008). In contrast to fruit ripening, an unequal distribution of the PD symptoms in the fruit flesh may be found as a result of the asymmetric progression of gelling. Also, accumulation of liquid is usually found in the seed cavity, observed when the gelled fruit is sectioned, suggesting problems in cell water entrance.

The lack of characterisation of these PDs in the literature may lead to a confused evaluation of the fruit due to the visual resemblance with mechanical injury. However, the symptoms of mechanical injury originate from the outer tissue, next to the epicarp (point of impact) and develop to the endocarp. In this case, the cell wall-degradation leads to a softening of the tissue (CHUNG et al., 2006), as a result of increase in ethylene biosynthesis (DE VRIES et al., 1999, STOW et al., 2000, ROSETTO et al., 2008). These symptoms are not observed in papaya gelling flesh; instead, the gelling aspect is usually observed as soon as the fruit are carefully detached from the papaya tree. Consequently, the aspect of the papaya mesocarp gel-like without doubt may not be caused by mechanical injury.

Studies of the anatomy and physiology of fruit crops may help to understand how the sequence of the metabolic events leads to the development of PDs. Until development of methods for the prevention of these disorders can be ensured, an understanding of the physiological factors associated with their development is required.

In order to characterize the gelled PD and to confirm that this disturb is not a premature ripening in papaya fruit flesh, measurements of electrolyte leakage, Pi content, lipid peroxidation, pulp firmness were carried out; mineral contents $(\mathrm{Ca}, \mathrm{Mg}$ e $\mathrm{K})$ in pulp and seed tissue were quantified; and histological analysis in pulp tissue of gelled papaya fruit were accomplished.

\section{MATERIAL AND METHODS}

Papaya (C. papaya L. 'Golden') fruits were utilised in all the experiments at the three-quarters yellow stage of maturity (fruit with $51-75 \%$ of yellow skin), according to Bron and Jacomino (2006). The number of replications was, at least, ten healthy and ten gelled fruit. The intact gelled fruits were identified in the Caliman Agrícola S/A packinghouse (Linhares, ES, Brazil) by sinking them in the water tank due to their higher density. The fruits were transported to the laboratory in refrigerated container. The time between sample collection and laboratory analysis was approximately 7 hours. In the laboratory, all of the fruits were weighed and cut in the middle, in a longitudinal section. The seeds were separated from the pulp by a spoon, weighed and counted. After firmness measurements, mesocarp samples were excised from the equatorial region of each fruit for soluble solids, electrolyte leakage, phosphate content, lipid peroxidation, anatomical and mineral analysis. After weighing and counting, the seeds were washed to eliminate the mucilage and mineral analysis was carried out. Healthy fruit were mechanically injured by dropping from a height of approximately $1.0 \mathrm{~m}$ to contrast with the gelling fruit for histological analyses.

The pulp firmness was determined by means of pulp penetration resistance measurements according to Fontes et al. (2008). Initially, each fruit was longitudinally sectioned in two faces. By using a bench penetrometer model 53205 (Fruit Pressure Tester, Italy) with an adaptor of $8 \times 8 \mathrm{~mm}$ (height $\mathrm{x}$ diameter), the firmness was determined at three equidistant points of each face, $5 \mathrm{~mm}$ inwards from the exocarp. The results were expressed in Newton (N) unit.

Soluble solids content were determined from juice pressed by hand and the percentage of soluble solids was determined with an Atago ATC-1 refractometer (Atago, Co., Tokyo, Japan).

The methodology to electrolyte leakage was conducted according to Vasquez-Tello et al. (1990) with some modifications. Five cylindrical samples $(10 \mathrm{~mm} \times 10 \mathrm{~mm})$ of each fruit were withdrawn from the fruit pulp to accomplish the electrolyte leakage measurements. After three washes in deionised water, the samples were immersed in $31 \mathrm{~cm}^{3}$ of ultra-pure water (Milli-Q Biocel/A10, Millipore, USA) and maintained at $12{ }^{\circ} \mathrm{C}$ for $24 \mathrm{~h}$. The free electrolyte leakage (FE) of the resultant solution was determined by means of a conductometer HI 8820N (Hanna Instruments, USA). The samples were heated at 80 ${ }^{\circ} \mathrm{C}$ for $1 \mathrm{~h}$ followed by $16 \mathrm{~h}$ at $12{ }^{\circ} \mathrm{C}$ to obtain the 
total electrolyte content (TE). All the measurements of conductivity were performed when solutions achieved room temperature $\left(25^{\circ} \mathrm{C}\right)$.

A $0.5 \mathrm{~cm}^{3}$ aliquot of each electrolytic solution was used for phosphate (Pi) release content determination, according to Fiske and Subbarow (1925).

About $500 \mathrm{mg}$ of fruit pulp tissue were used for lipid peroxidation measurements, according to Alonso et al. (1997). Lipid peroxidation was determined through the malondialdeyde (MDA) content in pulp tissue extracts. MDA is a subproduct of lipid peroxidation that, when it reacts with thiobarbituric acid (TBA), forms a red colour complex. MDA content was calculated by using an extinction coefficient $(\xi)$ of $155 \mathrm{mM}^{-1} \cdot \mathrm{cm}^{-1}$.

Pulp and seed tissues were sampled for mineral analysis. A total of fifteen replications were carried out for each fruit conditions (healthy and gelled). The samples were dried at $40{ }^{\circ} \mathrm{C}$ for 15 days. After drying, the seeds were ground in a Wileytype mill with a 20 mesh sieve and maintained in hermetically-closed flasks. From the ground tissue, a sample of $500 \mathrm{mg}$ was analysed for calcium $(\mathrm{Ca})$, magnesium $(\mathrm{Mg})$ and potassium $(\mathrm{K})$ mineral content. The determination followed the methodology of Jones et al. (1991). Potassium was quantified by flame emission spectrophotometry, whereas calcium and magnesium were determined by atomic absorption spectrophotometry, after a nitro-perchloric digestion $\left(\mathrm{HNO}_{3}\right.$ and $\left.\mathrm{HClO}_{4}\right)$.

To light microscopy, samples of fruit pulp tissue were fixed under low vacuum in Karnowsky solution (KARNOWSKY, 1965) for $2 \mathrm{~h}$, at room temperature. Dehydration was carried out in a graded ethanol series, followed by infiltration and embedding in $J B-4$ resin. Sections $(5-6 \mu \mathrm{m})$ were obtained in a manual microtome, and stained with toluidine blue $(0.05 \%)$ in phosphate buffer, $\mathrm{pH} 4.7)$, for $5 \mathrm{~min}$, rinsed in distilled water and air-dried. The sections were permanently mounted in Permount, and observed and documented using an upright AxioPlan (Zeiss, Jena, Germany) light microscope.

Samples of fruit pulp tissue were submitted to fixation and inclusion, following the standard preparation for electronic microscopy. The fruit fragments were fixed in $2.5 \%$ glutaraldehyde and 2.0 $\%$ paraformaldehyde in $0.05 \mathrm{M}$ cacodylate buffer, $\mathrm{pH}$ 7.2 and post-fixed in $2.0 \% \mathrm{OsO}_{4}$ during $2 \mathrm{~h}$. Samples were dehydrated in acetone, and critical-point-dried using $\mathrm{CO}_{2}$ in a Balzers CPD 080 apparatus and covered with $20 \mathrm{~nm}$ of gold (SCD $050 \mathrm{Bal}-\mathrm{Tec}$ ). Afterwards, the samples were examined under an electron microscope scanning (DSEM ZEISS 962).
To transmission electron microscopy, samples of fruit pulp tissue were fixed in an aqueous solution containing $2.5 \%$ glutaraldehyde and $4.0 \%$ paraformaldehyde in $0.05 \mathrm{M}$ cacodylate buffer $(\mathrm{pH}$ 7.2 ), under a low vacuum for $2 \mathrm{~h}$. Subsequently, the samples were rinsed and post-fixed in $2.0 \% \mathrm{OsO}_{4}$ during $2 \mathrm{~h}$. The post-fixed samples were dehydrated in a graded series of acetone solutions and embedded in epoxi resin (Polybed). The ultra-thin sections ( 80 $\mathrm{nm}$ ) were collected on copper grids (300 mesh), and stained with $1.0 \%$ uranyl acetate followed by $5.0 \%$ lead citrate. Sections were observed at $80 \mathrm{kV}$ using a transmission electron microscope (ZEISS EM 900).

Data were subjected to analyses of variance and Tukey test were used for mean separation when the $F$ test was significant at $P<0.05$.

\section{RESULTS AND DISCUSSION}

Papaya fruit showing a gelling aspect are characterised by a disturbance in mesocarp regions of the fruit, resembling a water-soaked appearance of the flesh tissue that is not externally visible until it has reached very advanced stages of development (Figures 1A and B). This pulp disturbance is thought to develop from the ovarian cavity to the exocarp direction with variable degrees and, when the entire pulp is gelled, the fruit is commercially disqualified. Figures $1 \mathrm{C}$ and $\mathrm{D}$ show healthy fruit after mechanical injury with pulp damage from the exocarp to the ovarian cavity, contrasting to pulp disturbance.

Table 1 shows significant decreases $(P<$ $0.05)$ in soluble solids, weight, total electrolyte content, total release of $\mathrm{Pi}, \mathrm{Mg}$ and $\mathrm{K}$ contents in gelled fruit. This shows a physico-chemical alteration of fruit however suggesting cell integrity of membranes of the gelled fruit, which are able to maintain the osmotic gradient between the cytosol and the apoplast, as also supported by microscopy analysis (Figures 2B, 3B, D and F). The maintenance of the physical integrity of membranes is an important factor related to stress tolerance, such as water stress (ROY-MACAULEY et al., 1992), chilling injury (MARANGONI et al., 1996) and plant senescence (PALLIYATH; DROILLARD 1992, MARANGONI et al., 1996). When comparing lipid peroxidation (Table 1 - estimated by MDA content), no significant differences $(P<0.05)$ were observed between the healthy and gelling fruit, reinforcing the hypothesis of the maintenance of the cellular integrity. Positive correlations between cellular integrity, lipid peroxidation levels and electrolyte leakage have also been reported by Alonso et al., (1997) in coffee seedlings under stress (chilling) 
conditions. Itzhaki et al. (1998) reported a decrease in phospholipid content as a major change in the membrane of the senescent rose petals.

According to Figure 2, morphological alterations were observed in gelling tissues, but without evident alterations in cell structure in healthy (A), gelling (B) and mechanically injured (C) treatments. However, these images revealed that, in the tissue of the healthy and mechanically injured papaya (Figures 2A and C), cells were entirely turgid and with little intercellular space. Gelled flesh tissue showed plasmolysed cells and large spaces between cells (Figure 2B), probably with water in the apoplast.

Light microscopy analysis corroborated the presence of more conspicuous intercellular spaces in the gelled flesh tissue (Figure 3D, arrow) when compared to healthy flesh tissue (Figure 3C). Transmission electron microscopy (Figures $3 \mathrm{E}$ and $\mathrm{F}$ ) demonstrated the integrity of both cells walls (healthy and gelled). However, the cells walls of gelled fruit showed deformity, with cellulose microfibril loosening (Figure 3F). These characteristics are typical of flesh tissues during fruit ripening (ALI; LAZAN, 1998), however soluble solids (Table 1) are not found, in discordance with the hypothesis of precocious ripening. The soluble solids content in ripe papaya is at least $11^{\circ}$ Brix (SOUZA et al., 2009).

In nectarines, the woolliness disturbance is related to the loss of cell membrane integrity when the cell fluids are released into the intercellular spaces and bind with pectin (VON MOLLENDORFF et al., 1992). In mango fruit with internal breakdown, a reduction in total pectins and pectinesterase activity were observed as well as a reduction of the firmness and the total soluble solids (TORRES \& SAÚCO, 2004). Pectic substances are capable of binding water, forming gel complexes implicated in the development of woolliness in peaches (BenArie \& Lavee, 1971) and in plum (TAYLOR et al., 1995). However, woolliness is associated with loss of juiciness (BEN-ARIE; LAVEE, 1971; TAYLOR et al., 1995), which was not observed in gelled as well as in healthy fruit. In addition, the results of the free electrolyte leakage (Table 1) and images (Figures 2 and 3) showed the physical integrity of the cellular membranes.

The physical integrity of the membrane per se does not reveal its functional integrity. The primary role of most membrane proteins is transport; such proteins include the $\mathrm{H}^{+}$-ATPases and $\mathrm{Ca}^{+2}$-ATPases pumps. The $\mathrm{H}^{+}$-ATPases work as electrogenic pumps and are able to utilise the energy associated with an electrochemical proton gradient across the membrane to drive the synthesis or hydrolysis of ATP (RATAJCZAK, 2000). In the vacuole, a $\mathrm{V}$-type $\mathrm{H}^{+}$-ATPase creates a $\mu \mathrm{H}^{+}$gradient across the tonoplast and this power is switched with ion transport, especially $\mathrm{K}$, into the vacuole. Therefore, any factor affecting this proton pump activity may interfere in the K-stimulated osmotic gradient generated across the tonoplast. According to Dietz et al. (1998), Mg deficiency may provoke osmotic changes in the vacuole as this ion is a cofactor and an important factor of regulation of the V-type $\mathrm{H}^{+}$-ATPase. As a consequence of lower K entry, the direction of the driving force might be altered and water is consequently forced out into intercellular spaces, resulting in the loss of the cellular tonus. In pineapple, it has been suggested that the decreased apoplastic osmotic potential, due the presence of sucrose in apoplast, and the subsequent increase of the water transfer into apoplast may favour the occurrence of pineapple translucency, a PD (CHEN; PAULL, 2000).

The $\mathrm{Ca}, \mathrm{Mg}$ and $\mathrm{K}$ contents in seeds (Table $1)$, was not different $(\mathrm{P}<0.05)$ among healthy and gelling fruit, indicating that there is no competition between pulp fruit and seed for these minerals in both healthy and gelling fruit. The lower values $(\mathrm{P}<0.05)$ to flesh $\mathrm{K}$ and $\mathrm{Mg}$ content and cell ionic content (as demonstrated by the total electrolyte content values) (Table 1) verified in gelled fruit, seem to be in agreement with the hypothesis of the water soaked appearance of the tissue. In addition, the penetration resistance did not differ significantly $(\mathrm{P}<0.05)$ between the gelled and healthy fruit. These data suggest that the fruit gelling aspect is neither associated a premature nor advanced ripening of the tissue, but to cell sap saturation in the flesh tissue caused primarily by its accumulation in the apoplast, rather than the vacuole.

It is generally accepted that fruit ripening is accompanied by the softening of the flesh tissue by enzymatic cell wall-degradation (BRADY, 1987, PAULL et al., 1999). The Ca bound to pectin in the cell wall has been associated with maintenance of the firmness of fruit (QIU et al., 1995), and Ca is the most commonly reported nutrient associated with postharvest disorders (FERGUSON; WATKINS, 1989). These statements, in addition to the detected values for the flesh $\mathrm{Ca}$ contents (Table 1), suggest that fruit gelling is neither due to premature ripening nor loss of cell wall-bound $\mathrm{Ca}$. The difference in $\mathrm{Ca}$ contents between healthy and gelling flesh tissue was not significant $(\mathrm{P}<0.05)$; these levels were higher than the critical $\mathrm{Ca}$ concentration for papaya (1.3 
mg.g-1 DW) proposed by Qiu et al. (1995). Studies in apples with application of Ca reveal that this element inhibits the solubilization process of the cell wall polyuronids, delaying the pulp softening process (GLENN; POOVAIAH, 1990).

The other physiological disorder with symptoms like as gelling is water-soaking in melon fruit (CHATENET et al., 2000). In these PD, a higher water mobility associated with a higher density was observed in water-soaked areas, as compared to sound tissues indicates an increase in the level of free water. These authors (CHATENET et al., 2000) also observed the presence of large intercellular spaces, as seen in gelling papaya fruit (Figures 2B and 3D). However, the melon tissue presented disorganisation of the cell wall, probably due, according to the authors, to the depletion of cell wall $\mathrm{Ca}$. The $\mathrm{Ca}$ has been directly involved in texture changes and the adequate $\mathrm{Ca}$ content of fruit at harvest is known to be crucial in maintaining fruit quality (SAMS, 1999). Ours data suggest that $\mathrm{Ca}$ does not participate in the development of the gelling disturbance.

In future studies, new approaches will be considered, such as field analyses of the climatic variables, besides the participation of $\mathrm{H}^{+}$-ATPases and the availability of energetic molecules in the beginning of the gelling disturbance. In addition, a better understanding of the cellular mechanisms related to gelling in papaya fruit may result in new subsidies that could be applied to the crop management avoiding, or at least minimising, the harmful effects of the PD.

TABLE 1 - Analysis of the characteristics of flesh and seeds of papaya (Carica papaya L. cv. Golden) healthy and gelled fruit.

\begin{tabular}{|c|c|c|}
\hline Characteristics analyzed & Healthy fruit $^{1}$ & Gelled fruit \\
\hline Pulp Firmness (N) & $1.85 \pm 0.27 \mathbf{a}$ & $2.08 \pm 0.30 \mathbf{a}$ \\
\hline Number of seeds & $494.83 \pm 37.09 \mathbf{a}$ & $461.50 \pm 32.72 \mathbf{a}$ \\
\hline Weight (g) & $333.20 \pm 10.78 \mathbf{a}$ & $310.37 \pm 15.70 \mathbf{b}$ \\
\hline Soluble solids $\left({ }^{\circ}\right.$ Brix $)$ & $10.00 \pm 0.11 \mathbf{a}$ & $12.4 \pm 0.60 \mathbf{b}$ \\
\hline Free electrolyte leakage * & $57.30 \pm 3.88 \mathbf{a}$ & $29.90 \pm 1.12 \mathbf{a}$ \\
\hline Total electrolyte content* & $363.40 \pm 12.32 \mathbf{a}$ & $265.90 \pm 34.83 \mathbf{b}$ \\
\hline Free release of $\mathrm{Pi}^{* *}$ & $0.004 \pm 0.001 \mathbf{a}$ & $0.002 \pm 0.001 \mathbf{a}$ \\
\hline Total release of $\mathrm{Pi}^{* *}$ & $0.018 \pm 0.001 \mathbf{a}$ & $0.014 \pm 0.001 \mathbf{b}$ \\
\hline Lipid peroxidation*** & $0.031 \pm 0.008 \mathbf{a}$ & $0.028 \pm 0.007 \mathbf{a}$ \\
\hline Pulp Ca content $* * * *$ & $2.67 \pm 0.43 \mathbf{a}$ & $1.63 \pm 0.31 \mathbf{a}$ \\
\hline Seeds Ca content $* * * *$ & $7.52 \pm 0.50 \mathbf{a}$ & $8.68 \pm 0.42 \mathbf{a}$ \\
\hline Pulp Mg content $* * * *$ & $3.43 \pm 0.44 \mathbf{a}$ & $1.95 \pm 0.17 \mathbf{b}$ \\
\hline Seeds Mg content $* * * *$ & $4.28 \pm 0.34 \mathbf{a}$ & $4.35 \pm 0.35 \mathbf{a}$ \\
\hline Pulp K content**** & $26.17 \pm 1.95 \mathbf{a}$ & $15.83 \pm 0.47 \mathbf{b}$ \\
\hline Seeds K content**** & $22.00 \pm 0.70 \mathbf{a}$ & $23.00 \pm 0.63 \mathbf{a}$ \\
\hline
\end{tabular}

${ }^{1}$ The data refer to the average $( \pm \mathrm{se})$ of at least ten fruit, picked at random from a sample of fruit of the orchard. The averages followed

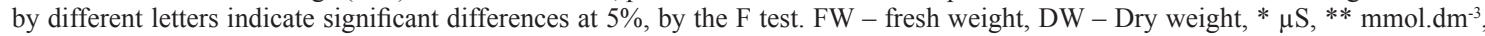
*** $\mu$ mol MDA. $\mathrm{mg}^{-1} \mathrm{FW}, * * * * \mathrm{~g} \cdot \mathrm{kg}^{-1} \mathrm{DW}$. 


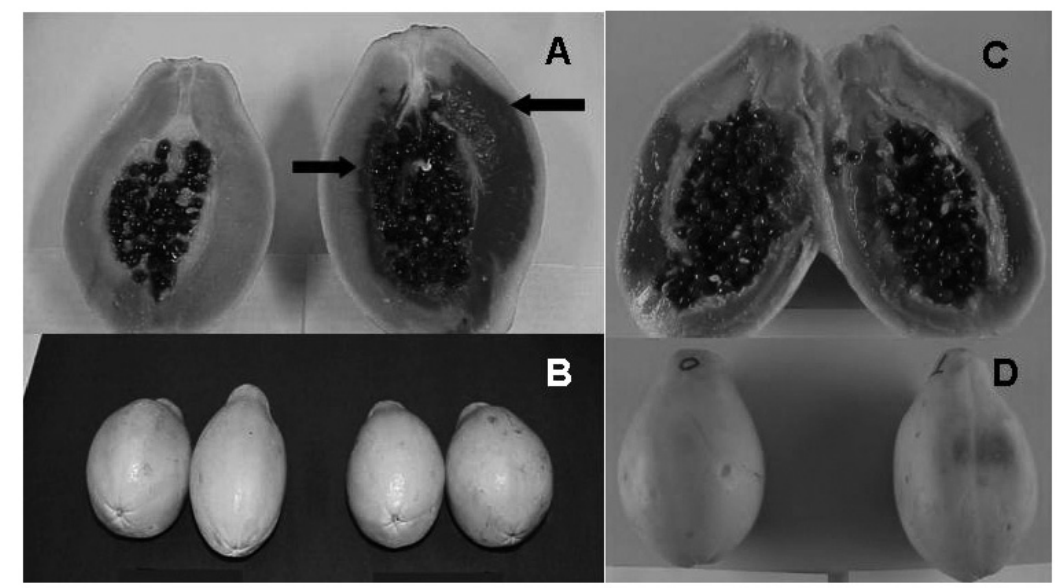

FIGURE 1 - (A) Photograph of the longitudinal sections of healthy (left) and gelled papaya fruit (right). Note arrows indicating the asymmetric symptoms in the gelling fruit pulp. (B) Photograph showing the normal external aspect in both healthy (left) and gelled (right) fruit. (C) Photograph of the longitudinal section of papaya submitted to mechanical injury. (D) Photographs show the normal external aspect of both healthy (left) and submitted to mechanical injury (right) fruit.

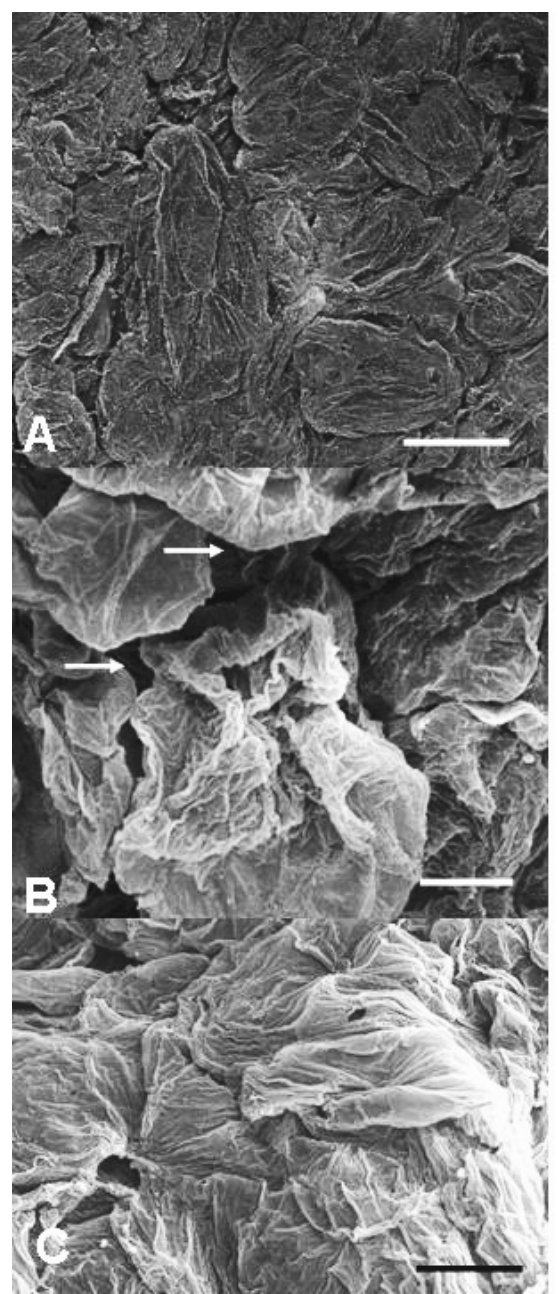

FIGURE 2 - Scanning electron micrographs of tissues of the healthy mesocarp (A), Bar $=100 \mu \mathrm{m}$; gelled mesocarp (B), Bar $=20 \mu \mathrm{m}$ and mechanically-injured papaya fruit (C), Bar $=20 \mu \mathrm{m}$. Note arrows indicating the intercellular spaces in $\mathrm{B}$. 


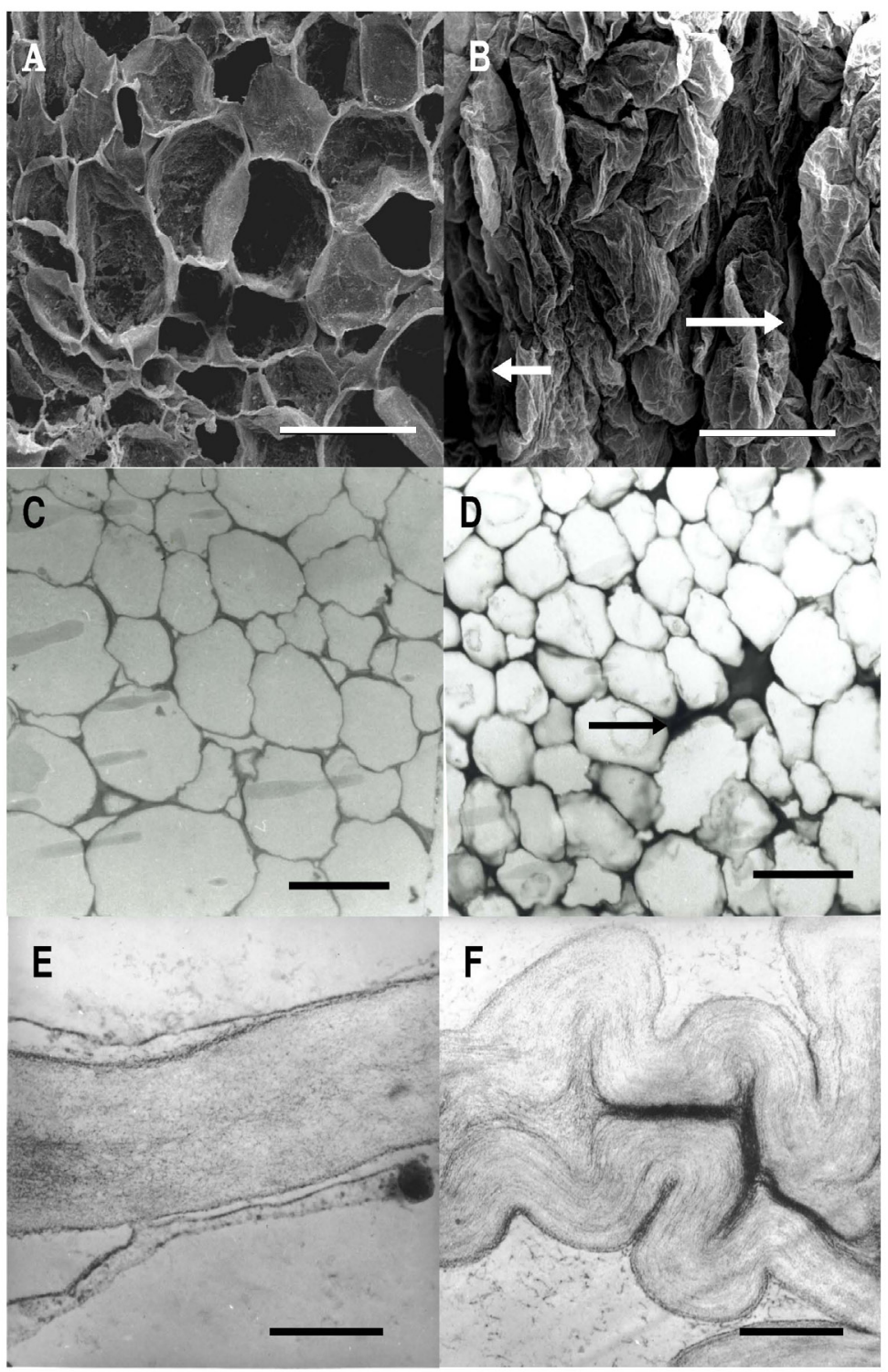

FIGURE 3 - Samples of healthy (A, C and E) and gelled (B, D and F) mesocarp papaya fruit. Scanning electron micrographs (A and B) show plasmolized cell and intercellular spaces in gelled fruit (arrows), Bars $=100 \mu \mathrm{m}$. Light microscopy $(\mathrm{C}$ and $\mathrm{D})$ show the intercellular space in gelled fruit (arrow), Bars $=20 \mu \mathrm{m}$. Transmission electron microscopy from cell wall (E and $\mathrm{F}$ ) showing disestablished cell wall in gelled fruit, Bars $=0.5 \mu \mathrm{m}$. 


\section{CONCLUSIONS}

Our results suggest that the gelling aspect of papaya fruit is neither due to premature ripening nor mechanical injury of the flesh. Data suggest that the inhibition of water transport to the vacuole, followed by the loss of cellular turgor pressure is the main causes of the PD. Moreover, the water soaked appearance of the tissue is due to the accumulation of water in the apoplast. There is no evidence of the participation of $\mathrm{Ca}$ in this disturbance. In future studies, new approaches will be considered such as the participation of $\mathrm{H}^{+}$ATPases and the availability of energetic molecules on the origin of this disturbance.

\section{ACKOWLEDMENTS} the fruit.

Thanks Caliman Agrícola S/A for supplying

\section{REFERENCES}

ALI, Z.M.; LAZAN, H.; Papaya. In: SHAW, P.E.; CHAN, H.T.; NAGY, S. (Ed.) Tropical and Subtropical fruits. Gainsville: Agscience, 1998. p. 401-445.

ALONSO, A.; QUEIROZ, C.S.; MAGALHÃES, A.C. Chilling stress leads to increased cell membrane rigidity in roots of coffee (Coffea arabica L.) seedlings. Biochimica et Biophysica Acta, Amsterdam, v.1323, p.75-84, 1997.

BEN-ARIE, R.; LAVEE, S. Pectic changes occurring in Elberta peaches sufferiing from woolly breakdown. Phytochemistry, Oxford, v.10, p.531-538, 1971.

BRADY, C.J. Fruit ripening. Annual Review of Plant Physiology, Palo Alto, v.38, p.155-178, 1987.

BRON, I.U.; JACOMINO, A.P. Ripening and quality of 'Golden' papaya fruit harvested at different maturity stages. Brazilian Journal of Plant Physiology, Londrina, v.18, p.389-396, 2006.

CHATENET, C.; LATCHÉ, A.; OLMOS, E.; RANTY, B.; CHARPENTEAU, M.; RANJEVA, R.; PECH, J. C.; GRAZIANA, A. Spatial-resolved analysis of histological and biochemical alterations induced by water-soaking in melon fruit. Physiologia Plantarum, Copenhagen, v.110, p.248-255, 2000.
CHEN, C.C.; PAULL, R.E. Sugar metabolism and pineapple flesh translucency. Journal of American Society for Horticulture Science, Alexandria, v.125, p.558-562, 2000.

CHUNG, T.T.; WEST, G.; TUCKER, G.A. Effect of wounding on cell wall hydrolase activity in tomato fruit. Postharvest Biology and Technology, Amsterdam, v.40, p.250-255, 2006.

DE VRIES, H.S.M.; HARREN. F.J.M.; REUSS, J. In situ, real-time monitoring of wound-induced ethylene in cherry tomatoes by two infrared laser-driven systems. Postharvest Biology and Technology, Amsterdam, v.6, p.275-285, 1999.

DIETZ, K-J.; HEBER, U.; MIMURA, T. Modulation of the vacuolar $\mathrm{H}^{+}$-ATPase by adenylates as basis for the transient $\mathrm{CO}_{2}$-dependent acidification of the leaf vacuole upon illumination. Biochimica et Biophysica Acta, Amsterdan, v.1373, p.87-92, 1998.

FERGUSON, I.B.; WATKINS, C.B. Bitter pit in apple fruit. Horticultural Reviews, New York, v.11, p.289-355, 1989.

FISKE, C.F.; SUBBAROW, Y. The colorimetric determination of phosphorus. Journal of Biological Chemistry, Baltimore, v.66, p.375-400, 1925.

FONTES, R.V.; SANTOS, M.P.; FALQUETO, A.R.; SILVA, D.M. Atividade da pectinametilesterase e sua relação com a perda de firmeza da polpa de mamão cv. Sunrise Solo e Tainung. Revista Brasileira de Fruticultura, Jaboticabal, v.30, p. 24-28, 2008.

GLENN, G.M.; POOVAIAH, B.W. Calcium mediated postharvest changes in texture and cell wall structure and composition in 'Golden Delicious' apples. Journal of American Society for Horticulture Science, Alexandria, v.115, p.962968,1990

ITZHAKI, H.; MAYAK, S.; BOROCHOV, A Phosphatidylcholine turnover during senescence of rose petals. Plant Physiology and Biochemistry, v. 36, p.457-462, 1998.

JONES JR, J.B.; WOLF, B.; MILLS, H. A Methods of elemental analysis. In: JONES JR, J. B. WOLF, B.; MILLS, H. Plant analysis handbook. Athens: Micro-Macro Publishing, 1991, p.27-38. 
KARNOWSKY, M.J.A formaldehyde-glutaraldehyde fixative of high osmolarity for use in electron microscopy. Journal of Cell Biology, New York, v.27, p.137A, 1965.

MARANGONI, A.G.; PALMA, T.; STANLEY, D.W. Membrane effects in postharvest physiology. Postharvest Biology and Technology, Amsterdam, v.7, p.193-217, 1996.

PALliYATH, G.; DROILlARD, M.J. The mechanisms of membrane deterioration and disassembly during senescence. Plant Physiology and Biochemistry, New Delhi, v.30, p.789-812, 1992.

PAULL, R.; GROSS, K.; QIU, Y. Changes in papaya cell walls during fruit ripening. Postharvest Biology and Technology, Amsterdam, v.16, p.79-89, 1999.

QIU, Y.; NISHINA, M.S.; PAULL, R.E. Papaya fruit growth, calcium uptake, and fruit ripening. Journal of American Society for Horticulture Science, Alexandria, v.120, p. 246-253, 1995.

RATAJCZAK, R. Structure, function and regulation of the plant vacuolar $\mathrm{H}^{+}$-translocating ATPase. Biochimica et Biophysica Acta, Amsterdan, v.1465, p.17-36, 2000.

ROY-MACAULEY, H.; ZUILY-FODIL, Y.; KIDRIC, M.; PHAM-THI, A. T.; VIEIRA DA SILVA, J. Effect of drought stress on proteolytic activities in Phaseolus and Vigna leaves from sensitive and resistant plants. Physiologia Plantarum, Copenhagen, v.85, p.9096, 1992.

ROSETTO, M.R.M.; NASCIMENTO, J.R.O.; PURGATTO, E.; FABI, J.P.; LAJOLO, F.M.; CORDENUNSI, B.R. Benzylglucosinolate, benzylisothiocyanate, and myrosinase activity in papaya fruit during development and ripening. Journal of Agricultural Food Chemistry, Davis, v. 56, p. 9592-9599, 2008.
SAMS, C.E. Preharvest factors affecting postharvest texture. Postharvest Biology and Technology, Amsterdam, v.15, p.249-254, 1999.

SOUZA, M.S., OLIVEIRA, J.G.; AZEVEDO, I.G.; CORRÊA, S.F.; SILVA, M.G.; PEREIRA, M.G.; Resposta da aplicação do 1-MCP em frutos de mamoeiro 'Golden' em diferentes estádios de maturação. Revista Brasileira de Fruticultura, Jaboticabal, v.31, n.3, p.693-700, 2009.

STOW, J.R.; DOVER, C.J.; GENGE, P.M. Control of ethylene biosynthesis and softening in 'Cox's Orange Pippin' apples during low-ethylene, low-oxygen storange. Postharvest Biology and Technology, Amsterdam, v.18, p.215-225, 2000.

TAYLOR, M.A.; RABE, E.; JACOBS, G.; DODD, M.C. Effect of harvest maturity on pectic substances, internal conductivity, soluble solids and gel breakdown in cold stored 'Songold' plums. Postharvest Biology and Technology, Amsterdam, v.5, p.285-294, 1995.

TORRES, A.C.; SAÚCO, V.G. The study of the problem of mango (Mangifera indica L.) internal breakdown. Acta Horticulture, Wageningen, v.645, p.167-174, 2004.

VASQUEZ-TELLO, A.; ZUILY-FODIL, Y.; PHAM-THI, A.; VIEIRA DA SILVA, J. Eletrolyte and Pi leakages and soluble sugar content as physiological tests for screening resistance to water stress in Phaseolus and Vigna species. Journal of Experimental Botany, Oxford, v.41, p.827-832, 1990.

VON MOLLENDORFF, L.J.; JACOBS, G.; DE VILLIERS, O.T. Cold storange influences internal characteristics of nectarines during ripening. HortScience, Alexandria, v.27, p.1295-1297, 1992. 